\title{
Waterborne zinc alters temporal dynamics of guppy Poecilia reticulata epidermal response to Gyrodactylus turnbulli (Monogenea)
}

\author{
Cristina Gheorghiu ${ }^{1, *}$, David J. Marcogliese ${ }^{2}$, Marilyn E. Scott ${ }^{3}$ \\ ${ }^{1}$ Department of Biology \& Chemistry, Faculty of Science, Wilfrid Laurier University, 75 University Avenue West, Waterloo, \\ Ontario N2L 3C5, Canada \\ ${ }^{2}$ Fluvial Ecosystem Research Section, Aquatic Ecosystem Protection Research Division, \\ Water Science and Technology Directorate, Science and Technology Branch, Environment Canada, St. Lawrence Centre, 105 \\ McGill, 7th Floor, Montreal, Quebec H2Y 2E7, Canada \\ ${ }^{3}$ Institute of Parasitology, Macdonald Campus of McGill University, 21111 Lakeshore Road, Ste-Anne de Bellevue, \\ Quebec H9X 3V9, Canada
}

\begin{abstract}
The present study assessed the histological changes in the epidermis of Poecilia reticulata induced by the combined effects of an ectoparasite Gyrodactylus turnbulli and differing concentrations of waterborne zinc (Zn). Infected guppies were exposed to $0,15,30,60$, or $120 \mu \mathrm{g}$ $\mathrm{Zn}^{-1}$ and monitored over $3 \mathrm{wk}$ during the exponential increase in parasite numbers on the fish. The fish epidermis responded within $3 \mathrm{~d}$ to $G$. turnbulli infection with a rapid increase in epidermal thickness and a modest increase in number, but not size or composition, of mucous cells. In contrast, in the presence of combined waterborne $\mathrm{Zn}$ and infection, mucous cell numbers declined rapidly. As the parasite numbers increased, the epidermis remained thicker than normal, and the number and size of mucous cells decreased. The addition of $\mathrm{Zn}$ led to a dramatic thickening of the epidermis during the exponential growth of the parasite population. Mucous cell numbers remained depressed. Temporal changes in mucous cell size were $\mathrm{Zn}$ concentration dependent. At $60 \mu \mathrm{g} \mathrm{Zn} \mathrm{l^{-1 }}$, cells returned to normal size as infection progressed, whereas they remained

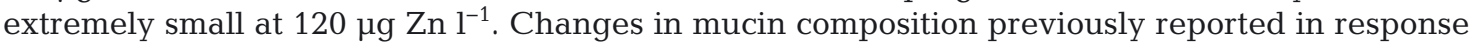

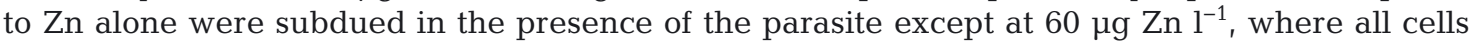
contained only acidic mucins. Together these results demonstrate that, on exposure to both Zn and G. turnbulli infection, the epidermal response is initially a protective response to both stressors, and then mainly driven by the increased parasite burden.
\end{abstract}

KEY WORDS: Waterborne zinc · Poecilia reticulata - Gyrodactylids · Epidermal histology · Mucous cells $\cdot$ Mucins

\section{INTRODUCTION}

Gyrodactylids are important monogenean ectopathogens in aquaculture, fisheries, and hobbyist markets, affecting species in many families of marine and freshwater teleost fishes. These small epidermal browsers cause mechanical disruption of the epithe- lium while feeding and moving over the skin, fins, and gills (Kearn 1998, Cone 1999). They are viviparous, and introduction of a single parasite onto the skin of the host results in exponential growth of parasite numbers that continues until the damage induced by infection kills the fish or until the host response leads to a decline in parasite numbers. The 
infection dynamics on an individual host are highly variable depending on the intensity of the host response to parasite assault (Scott \& Robinson 1984, Scott 1985, Richards \& Chubb 1996, 1998) and on environmental conditions including exposure to pollutants such as waterborne zinc (Zn) that reduces the rate of parasite population growth on isolated guppies (Gheorghiu et al. 2007).

The epidermis is a metabolically active tissue that responds to Gyrodactylus infection with increased mucus secretion (Lester \& Adams 1974, Scott \& Anderson 1984) and thickening of the epithelium, evidenced as an increase in the number of epidermal cell layers (Appleby et al. 1997) and hyperplasia of epidermal cells (Wells \& Cone 1990). Gyrodactylidinfected trout and salmon have reduced mucous cell density (Wells \& Cone 1990, Sterud et al. 1998), but the opposite is seen in gyrodactylid-infected flounder (Barker et al. 2002). Parasites preferentially move away from microenvironments with high densities of mucous cells (Buchmann \& Bresciani 1998), perhaps because their survival and reproduction are dependent not only on parasite chemoattractants and host anti-parasitic factors but also on the composition of mucus (Buchmann 1999, Buchmann \& Lindenstrøm 2002). Mucus also plays an important role in protecting fish skin against waterborne heavy metals such as Zn. Zn was chosen because (1) it is an essential microelement (Watanabe et al. 1997) present in every cell and involved in the structure or function of more than 300 enzymes and proteins (Vallee \& Falchuk 1993, Cousins 1998); (2) at elevated concentrations, it becomes an important toxicant (Widianarko et al. 2000, 2001); (3) it is one of the most common aquatic pollutants (Bowen et al. 2006), affecting both fish (Atchison et al. 1987, Bowen et al. 2006) and parasites (Sures 2002, Morley et al. 2003a,b, Thielen et al. 2004) in many ways; and (4) the reported toxic concentrations for fish and parasites are within the same order of magnitude, whereas other heavy metals are much more toxic for the fish than for aquatic stages of parasites (Cross et al. 2001, Canadian Council of Ministers of the Environment 2005, Pietrock \& Goater 2005).

Fish respond to waterborne $\mathrm{Zn}$ by increased release of mucus which contains acidic mucins that bind and precipitate $\mathrm{Zn}$, thus regulating its absorption by preventing it from reaching the uptake surfaces (Handy et al. 1989, Shephard 1994). We have recently characterized the epidermal response of guppy fry to waterborne $\mathrm{Zn}$ at sublethal concentrations ranging from 15 to $120 \mu \mathrm{Zn} \mathrm{l}^{-1}$ (Gheorghiu et al. 2009). Mucous cell numbers declined by about
$50 \%$ in fish exposed to these concentrations of $\mathrm{Zn}$, and much of the fish surface was covered with mucus at $3 \mathrm{~d}$ post exposure to $\mathrm{Zn}$. Mucus production, numbers, and size of mucous cells, as well as epidermal thickness fluctuated, especially over the first $18 \mathrm{~d}$ in a concentration-dependent manner. Shortly after Zn exposure, epidermal thickness increased at lower $\mathrm{Zn}$ concentrations but decreased at higher $\mathrm{Zn}$ concentrations.

Of particular interest was the observed concentration-dependent shift in mucin composition within the mucous cells. Precursor mucous cells normally contain only neutral mucins (Sinha \& Chakravorty 1982). As these cells mature, some neutral mucopolysaccharides are transformed into acidic mucopolysaccharides and new acid mucopolysaccharides are synthesized. Once the cells are mature, they contain a complex mixture of acidic and neutral polysaccharides (Sinha \& Chakravorty 1982). Acidic mucins have antibacterial properties (Kamisago et al. 1996, Hirmo et al. 1998), and trap Zn, thus preventing its passage across the host epidermis (Handy et al. 1989, Shephard 1994). We observed a rapid and sustained shift to acidic mucins within $3 \mathrm{~d}$ of exposure of guppies to 15 or $60 \mu \mathrm{g} \mathrm{Zn}^{-1}$, but a much more delayed shift at $120 \mu \mathrm{Zn} \mathrm{l}^{-1}$ (Gheorghiu et al. 2009).

In the present study, we recorded the temporal changes in the epidermis of guppies Poecilia reticulata induced by infection with Gyrodactylus turnbulli combined with waterborne $\mathrm{Zn}$ in order to characterize the skin response to infection and to determine whether this response was altered by concurrent exposure to different concentrations of waterborne $\mathrm{Zn}$. We hypothesized that the previously reported impairment in growth of G. turnbulli populations on guppies simultaneously exposed to waterborne $\mathrm{Zn}$ (Gheorghiu et al. 2007) was linked to altered epidermal responses. We also hypothesized that the epidermal response to infection would be more evident during the late exponential growth phase of infection, when parasite numbers were highest, than shortly after infection. Finally, we hypothesized that the evidence of acclimation of the epidermal tissue observed in response to $\mathrm{Zn}$ alone (Gheorghiu et al. 2009) would also be observed in response to the combined stresses of $\mathrm{Zn}$ and infection. Guppies are useful test animals in aquatic experiments because they are easy to maintain and breed under laboratory conditions and they are able to survive at very high concentrations of Zn (Widianarko et al. 2000, 2001). Also, G. turnbulli burdens can be repeatedly monitored over time on individual hosts, as the parasites only live on the skin and fins. 


\section{MATERIALS AND METHODS}

The experiments were performed on guppy fry of 0.5 to $1.0 \mathrm{~cm}$ standard body length, bred in our laboratory from a strain of feeder guppies purchased from a local pet store, and naïve to Gyrodactylus turnbulli. The experimental fry were maintained in individual rectangular plastic containers in $200 \mathrm{ml}$ waterborne $\mathrm{Zn}$ solution at $25^{\circ} \mathrm{C}$ with $16 \mathrm{~h}$ light: $8 \mathrm{~h}$ dark cycle and were fed on a Nutrafin Max Complete Flake diet once a day. The strain of G. turnbulli was initially isolated from infected guppies from a local supplier, identified according to Harris et al. (1999), and maintained by weekly addition of naïve fish into infected stock populations. All procedures were approved by a McGill University Animal Care Committee, in accordance with guidelines of the Canadian Council on Animal Care (2005) in place at the time the research was conducted.

The range of concentrations of $\mathrm{Zn}$ selected was based on the maximal admissible limit for aquatic life (30 $\mathrm{g} \mathrm{l}^{-1} \mathrm{Zn}$ ) according to the Canadian Council of Ministers of the Environment (2005). Solutions were prepared according to the method described by Gheorghiu et al. (2006) by adding 0 (as control), or 15, 30, 60 , or $120 \mu \mathrm{g} \mathrm{l}^{-1} \mathrm{Zn}$ to artificial freshwater that con-

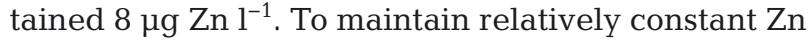
concentrations throughout the experiments, Zn solutions were replaced every $2 \mathrm{~d}$ (Gheorghiu et al. 2006). For convenience, results will be presented according to the concentration of $\mathrm{Zn}$ added to the artificial freshwater.

Guppies were experimentally infected with 3 parasites transferred on a scale or piece of fin from an infected donor onto the caudal peduncle of a naïve recipient, as previously described (Scott 1982, Gheorghiu et al. 2006). Infections were performed using a stereomicroscope with cold light while fish were anaesthetized for a maximum of $5 \mathrm{~min}$ in $50 \mathrm{ml}$ of $0.02 \%$ tricaine methanesulfonate (Finquel MS-222, Argent Chemical Laboratories) buffered to a neutral pH with $\mathrm{NaHCO}_{2}$. After the experimental infection, fry were placed individually in plastic containers with $200 \mathrm{ml}$ of the respective $\mathrm{Zn}$ solution, and infections were monitored daily.

In designing this experiment, it was necessary to control for the number of parasites per fish, as Gyrodactylus turnbulli reproduce directly on their host and there is high variability in parasite population dynamics on isolated hosts (Scott \& Anderson 1984). Thus, the epidermal response was recorded prior to infection and at 4 phases following infection. Given the high variability in parasite numbers at any specific time post infection, we controlled for infection intensity rather than days of exposure to $\mathrm{Zn}$ on the assumption that the type and magnitude of the host response was more directly related to parasite intensity than days post infection. Four infection phases were selected: the lag period (less than 6 parasites per fish), early exponential growth (approximately 20 parasites per fish), mid-exponential growth (approximately 50 parasites per fish), and late exponential growth (approximately 100 parasites per fish). In order to characterize the epidermal response to the parasite alone and in combination with waterborne $\mathrm{Zn}$, the 4 phases of infection were used as points of reference. For each fish, we recorded the day post infection when the parasite numbers reached each of the 4 phases of infection. Thus, for each Zn concentration, we were able to calculate the mean and SE day when fish were at each phase of infection. This allowed us not only to compare epidermal responses across $\mathrm{Zn}$ concentrations, but also to make comparisons with our previous study where responses to $\mathrm{Zn}$ alone were reported (Gheorghiu et al. 2009). Histological analysis of 3 fish per $\mathrm{Zn}$ concentration was conducted prior to infection and at each of the 4 phases of infection according to procedures described in Gheorghiu et al. (2009). Briefly, fry were killed in MS-222, fixed in Bouin's solution, and then stored in $70 \%$ ethanol. Paraffin cross-sections $(5 \mu \mathrm{m})$ of the caudal peduncle were cut and stained using either hematoxylin and eosin (H\&E) for overall structure, or combined periodic acid-Schiff with Alcian Blue $2 \%$ (PAB) to differentiate between neutral polysaccharides and acidic mucopolysaccharides contained in the mucous cell (Tibbetts 1997). We recorded epidermal thickness, number of epidermal cell layers, and number of mature mucous cells, their size, location, and mucin composition from 4 lateral fields of view, each of $0.24 \mathrm{~mm}^{2}$, chosen randomly in each of 3 serial crosssections of the caudal peduncle of each fish.

The temporal effect of combined waterborne $\mathrm{Zn}$ exposure and Gyrodactylus turnbulli infection on the guppy epidermis was assessed using $\chi^{2}$ for categorical variables (mucin composition, mucous cell location) and 2-way ANOVA using PROC GLM to compare the time course of parasite population growth. Continuous histological variables were analyzed by 2-way ANOVA using PROC MIXED with a nested model that controlled for degrees of freedom and post-hoc contrasts across time/phase of infection within each $\mathrm{Zn}$ concentration using the LSMEANS option. The mean and SE are reported. Analyses were performed using SAS ver. 9.1 software. The level of significance was established at $\mathrm{p}<0.05$; statistics are reported only for significant effects. 


\section{RESULTS \\ Effect of Zn concentration on parasite population dynamics}

Two-way ANOVA revealed significant effects of Zn $\left(F_{4,84}=9.30, \mathrm{p}<0.0001\right)$, Time $\left(F_{5,84}=1387.85\right.$, $\mathrm{p}<0.0001)$ and their interaction $\left(F_{18,84}=2.59, \mathrm{p}<\right.$ 0.0001 ) on parasite population growth. Fish kept in 0 and $15 \mu \mathrm{g} \mathrm{Zn} \mathrm{l}^{-1}$ displayed classical parasite population dynamics, with a short lag period followed by a gradual exponential growth (Fig. 1A,B). When infected fish were exposed to 30 to $120 \mu \mathrm{g} \mathrm{Zn} \mathrm{l^{-1 }}$ (Fig. 1C-E), exponential growth was delayed, with fish only reaching 100 parasites after approximately $18 \mathrm{~d}$, compared to $11 \mathrm{~d}$ in those kept in 0 and $15 \mu \mathrm{gn} \mathrm{l}^{-1}$.

\section{Epidermal thickness and cell layers}

Concurrent gyrodactilid infection and Zn exposure significantly affected the guppy epidermis, as revealed by 2-way ANOVA (Table 1). Compared to the control (Fig. 2A), infection alone induced almost a $50 \%$ increase in the thickness of the epidermis within $3 \mathrm{~d}$, which was then maintained at the same level throughout exponential growth of the parasite population (Figs. 2B \& 3A). In infected fish concurrently exposed to $\mathrm{Zn}$ (Fig. 3B-E), a thickening of the epidermis was also observed at the beginning of the exponential growth phase when parasite numbers were approximately 20 (Days 9-10) (Fig. 3B-E). The epidermis continued to thicken in those fish exposed to $15 \mu \mathrm{g} \mathrm{Zn} \mathrm{l}^{-1}$, reaching more than twice the initial thickness, and $50 \%$ more than fish not exposed to Zn with similar numbers of parasites (Figs. 2C \& 3B). In marked

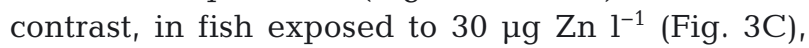
epidermal thickness declined to baseline levels as exponential growth of the parasite population continued. At higher $\mathrm{Zn}$ concentrations, as the number of parasites continued to increase, the thickness declined and then increased again (Fig. 3D,E). The number of cell layers mirrored this pattern indicating hyperplasia of epithelial cells (data not shown).

\section{Mucous cell response}

Infection induced a modest increase in mucous cell numbers (Fig. 4A) but a decrease in cell size
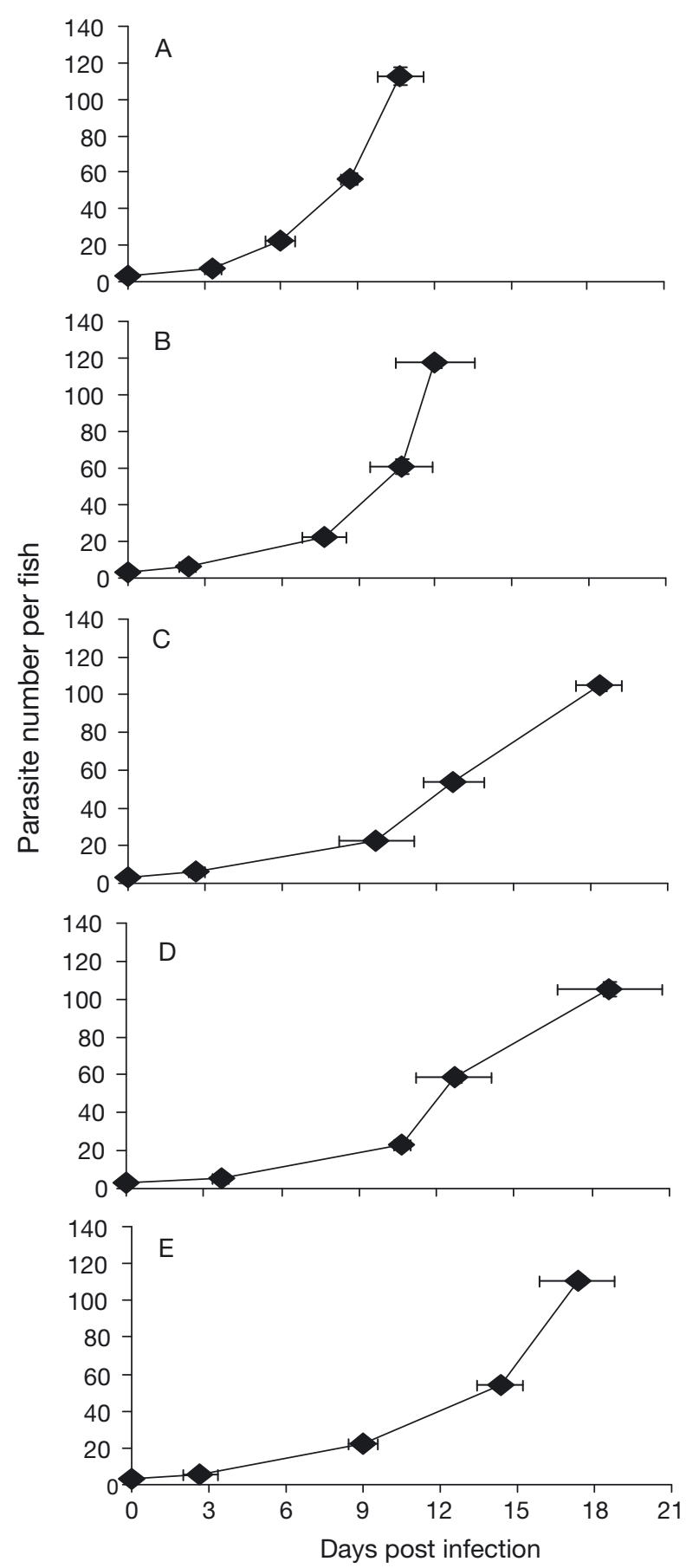

Fig. 1. Number of Gyrodactylus turnbulli on Poecillia reticulata and associated average time post-infection at the 5 phases of infection: pre-exposure; lag period $(<6$ parasites per fish); early exponential growth phase (approximately 20 parasites per fish); mid-exponential growth phase (approximately 50 parasites per fish); and late exponential growth phase (approximately 100 parasites per fish). Isolated guppies were maintained in water containing (A) 0 ,

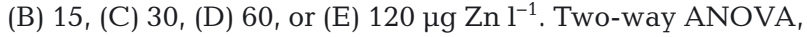
main effects: $\mathrm{Zn}, \mathrm{p}<0.0001$; Time, $\mathrm{p}<0.0001 ; \mathrm{Zn} \times$ Time, $\mathrm{p}<$ 0.0001). Error bars: SE 
Table 1. Two-way ANOVA and chi-squared analysis of Zn concentration and gyrodactilid infection on histological parameters of the guppy epidermis

\begin{tabular}{|c|c|c|c|}
\hline \multirow{2}{*}{ Parameter } & \multicolumn{3}{|c|}{ - Effects } \\
\hline & $\mathrm{Zn}$ & Infection & Zn $\times$ Infection \\
\hline Skin thickness & $F_{4,16.7}=3.57(\mathrm{p}=0.00279)$ & $F_{4,588}=34.77(\mathrm{p}<0.0001)$ & $F_{12,806}=13.49(\mathrm{p}<0.0001)$ \\
\hline Epithelial cell layers & $F_{4,14.3}=16.24(\mathrm{p}<0.0001)$ & $F_{4,513}=19.64(\mathrm{p}<0.0001)$ & $F_{12,805}=11.21(\mathrm{p}<0.0001)$ \\
\hline Mucous cell number & $F_{4,18.4}=4.52(\mathrm{p}=0.0102)$ & $F_{4,547}=24.42(\mathrm{p}<0.0001)$ & $F_{12,777}=4.77(\mathrm{p}<0.0001)$ \\
\hline Mucous cell size & $F_{4,25.1}=9.12(\mathrm{p}<0.0001)$ & $F_{4,468}=21.92(\mathrm{p}<0.0001)$ & $F_{12,1103}=5.17(p<0.0001)$ \\
\hline Mucous cell location & & $\chi^{2} 32=265.78(p<0.0001)$ & \\
\hline Mucous cell type & & $\chi_{44}^{2}=809.03(p<0.0001)$ & \\
\hline
\end{tabular}

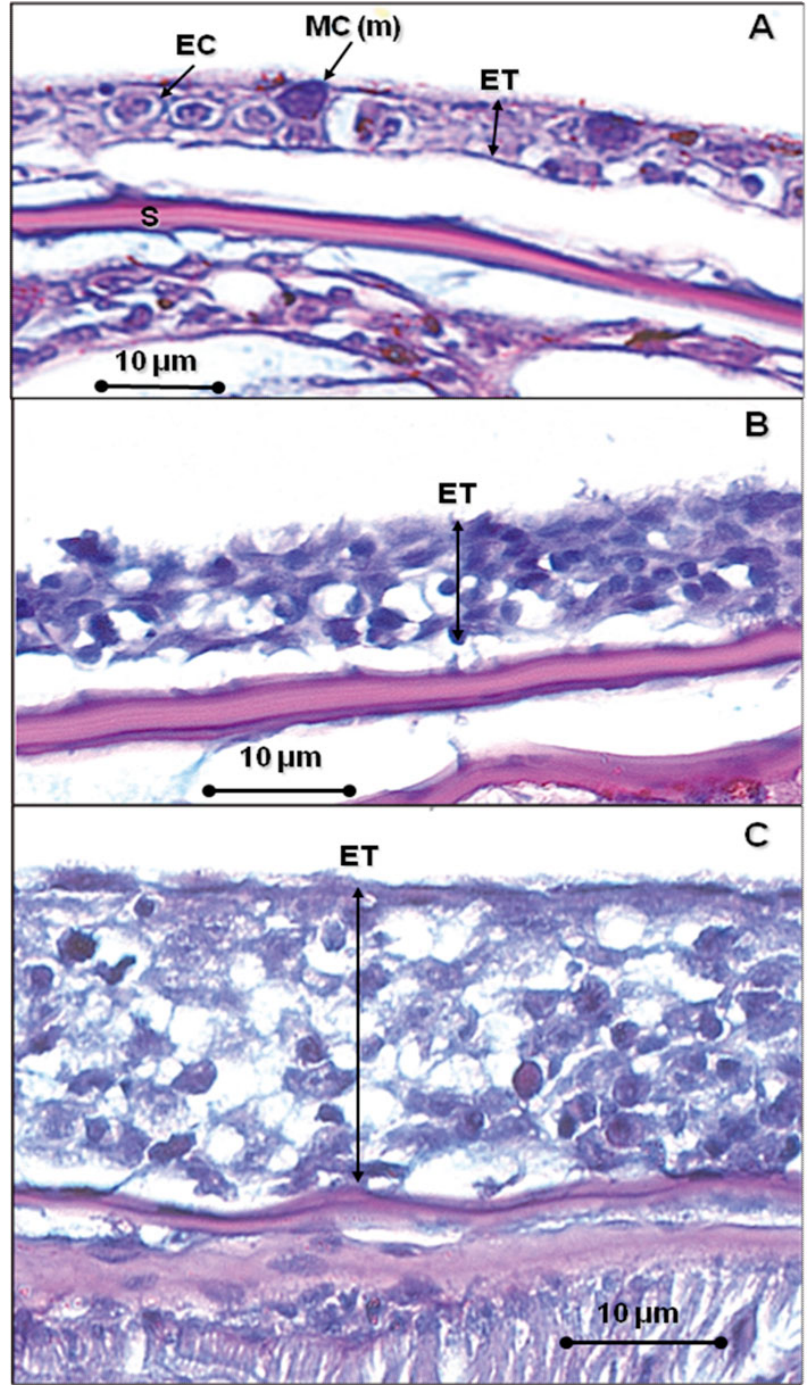

Fig. 2. Histological images of epidermis of Poecillia reticulata (periodic acid-Schiff [PAB] staining; 425x) in response to Gyrodactylus turnbulli and $\mathrm{Zn}$. (A) Epidermis of control fish, uninfected and unexposed to Zn. ET: thickness of epidermis; EC: epithelial cells; MC (m): mucous cells with a mixture of neutral and acidic mucins; S: scale. (B) Moderate thickening of the epidermis in fish infected with G. turnbulli, on Day 3 post-infection. (C) Extreme thickening of the epidermis in

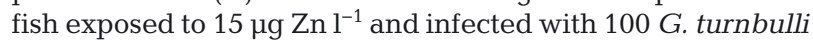

(Fig. 4F) during the lag phase of infection, after which both mucous cell numbers and size declined significantly and remained low throughout the exponential growth of the parasite population. In contrast, exposure of infected fish to $\mathrm{Zn}$ induced a rapid and dramatic drop in both the number (Fig. 4B-E) and size (Fig. 4F-J) of mucous cells during the $3 \mathrm{~d}$ lag phase. As with infected fish not exposed to $\mathrm{Zn}$, mucous cell numbers remained depressed throughout the period of infection (Fig. 4B-E). Notably, very few mucous cells were observed when parasite numbers reached 100 at $60 \mu \mathrm{g} \mathrm{Zn} \mathrm{l^{-1 }}$ (Fig. 4D; Day 19), but these few cells were of normal size (Fig. 4I; Day 19). In contrast, mucous cells remained very small in fish kept at $120 \mu \mathrm{g} \mathrm{Zn} \mathrm{l}^{-1}$ (Fig. 4J).

Prior to exposure to infection or $\mathrm{Zn}, 98 \%$ of mature mucous cells were located on the external surface of the epidermis (Table 2), and more than $60 \%$ of mature mucous cells continued to be found on the external surface as infection progressed. The notable

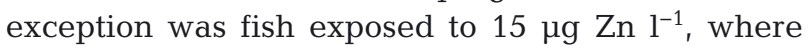
only $8 \%$ of mature mucous cells were on the external surface of the skin (Table 2).

Infection alone exerted a modest effect on the composition of mucins, and only during the midexponential growth phase when cells containing only acidic or only neutral mucins were observed (Fig. 5A). A similar pattern of mucin composition over time was observed in infected fish exposed to 15, 30, and $120 \mu \mathrm{g} \mathrm{Zn} \mathrm{l}^{-1}$ (Fig. 5B,C,E), although the shift to more acidic or neutral mucins emerged earlier in infected fish exposed to $15 \mu \mathrm{g} \mathrm{Zn} \mathrm{l}^{-1}$ (Fig. 5B), and $100 \%$ of mucous cells contained neutral mucins during the late exponential growth phase in fish exposed to $30 \mu \mathrm{g} \mathrm{Zn} \mathrm{l^{-1 }}$ (Fig. 5C). A very different pattern was seen in fish maintained

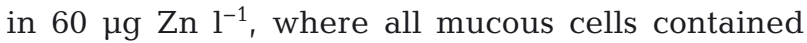
only acidic mucins throughout the infection period (Fig. 5D). 

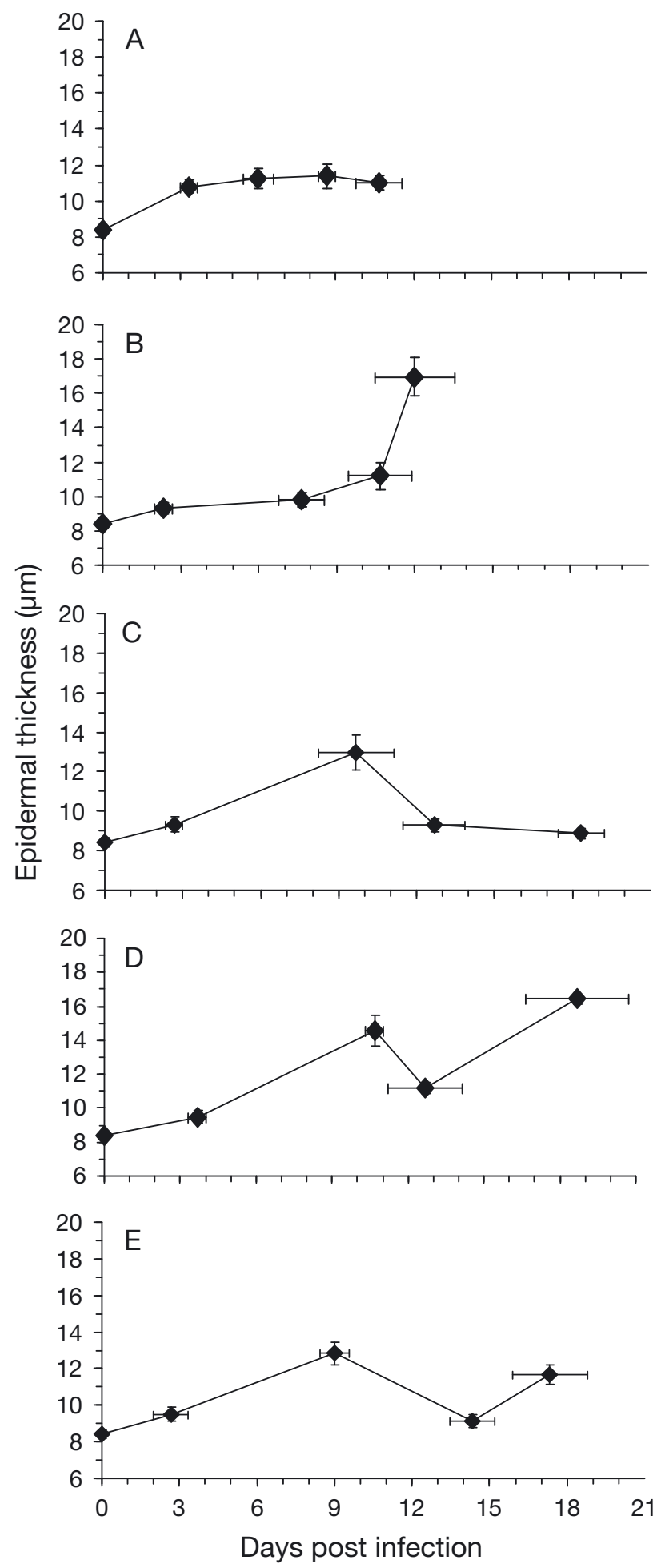

Fig. 3. Temporal dynamics of epidermal thickness of Poecillia reticulata in response to Gyrodactylus turnbulli and Zn. (A) G. turnbulli; (B) G.turnbulli and $15 \mu \mathrm{Z} \mathrm{Zn} \mathrm{l}^{-1}$; (C) G. turnbulli and $30 \mu \mathrm{Zn} \mathrm{l}^{-1}$; (D) G. turnbulli and $60 \mu \mathrm{gn} \mathrm{l}^{-1}$; (E) G. turn-

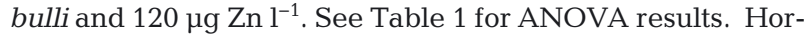
izontal bars represent SE in the day when fish reach lag, early, middle and late exponential growth phases of infection

\section{DISCUSSION}

The present study reports for the first time the temporal dynamics of the epidermal response of fish to gyrodactylid parasites, and the impact of concurrent waterborne zinc exposure. The initial response to the combined stresses was dominated by the response to Zn and perhaps a secondary suppressive effect of the parasite. As the parasite burden was very low during the first few days of $\mathrm{Zn}$ exposure, it is most likely that Zn was initially the main stressor. The exposure to both $\mathrm{Zn}$ and infection initially induced a rapid and dramatic drop in mucous cell numbers and size and only a moderate thickening of the epidermis, similar to effects detected in response to Zn alone (Gheorghiu et al. 2009). Intriguingly, the delayed shift in mucus composition observed in fish concurrently exposed to both stressors might be attributed to the secondary suppressive effect of the parasite. The later responses were dominated by the infection, as evidenced by sustained depression of mucous cell numbers and absence of shift in mucin composition. The dominant effect of infection during this period is likely because parasite numbers were increasing exponentially, whereas Zn concentration remained stable.

Gyrodactylus turnbulli infection initially induced a modest increase in mucous cell numbers with no shift in mucin composition, in contrast to the rapid decrease and change in composition in response to $\mathrm{Zn}$ alone (Gheorghiu et al. 2009). In addition, infection induced a rapid but moderate thickening of the epidermis even though parasite numbers at this time were very low. The initial response to combined Zn and infection exposure appears to have been driven mainly by $\mathrm{Zn}$, especially at concentrations $>15 \mu \mathrm{g}$ $\mathrm{Zn}^{-1}$. Mucous cell numbers decreased, but epidermal thickness was only modestly affected. These are all features of the immediate host response to $\mathrm{Zn}$ (Gheorghiu et al. 2009). Given the low numbers of parasites on the fish at this early stage of infection, it was not surprising that $\mathrm{Zn}$ emerged as the more dominant driver of the host response.

Despite the low parasite intensity shortly after infection, our data indicate that the presence of only a few Gyrodactylus turnbulli dramatically decreased both the size of the mucous cell and the proportion of the mature mucous cells located on the surface of the epidermis. As the parasite numbers increased, the mucous cell size either fluctuated, but remained

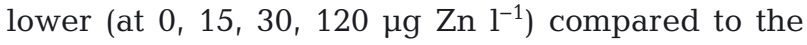
control (no Zn, no infection) or, on the contrary, started to increase to reach the normal size (at $60 \mu \mathrm{g}$ 

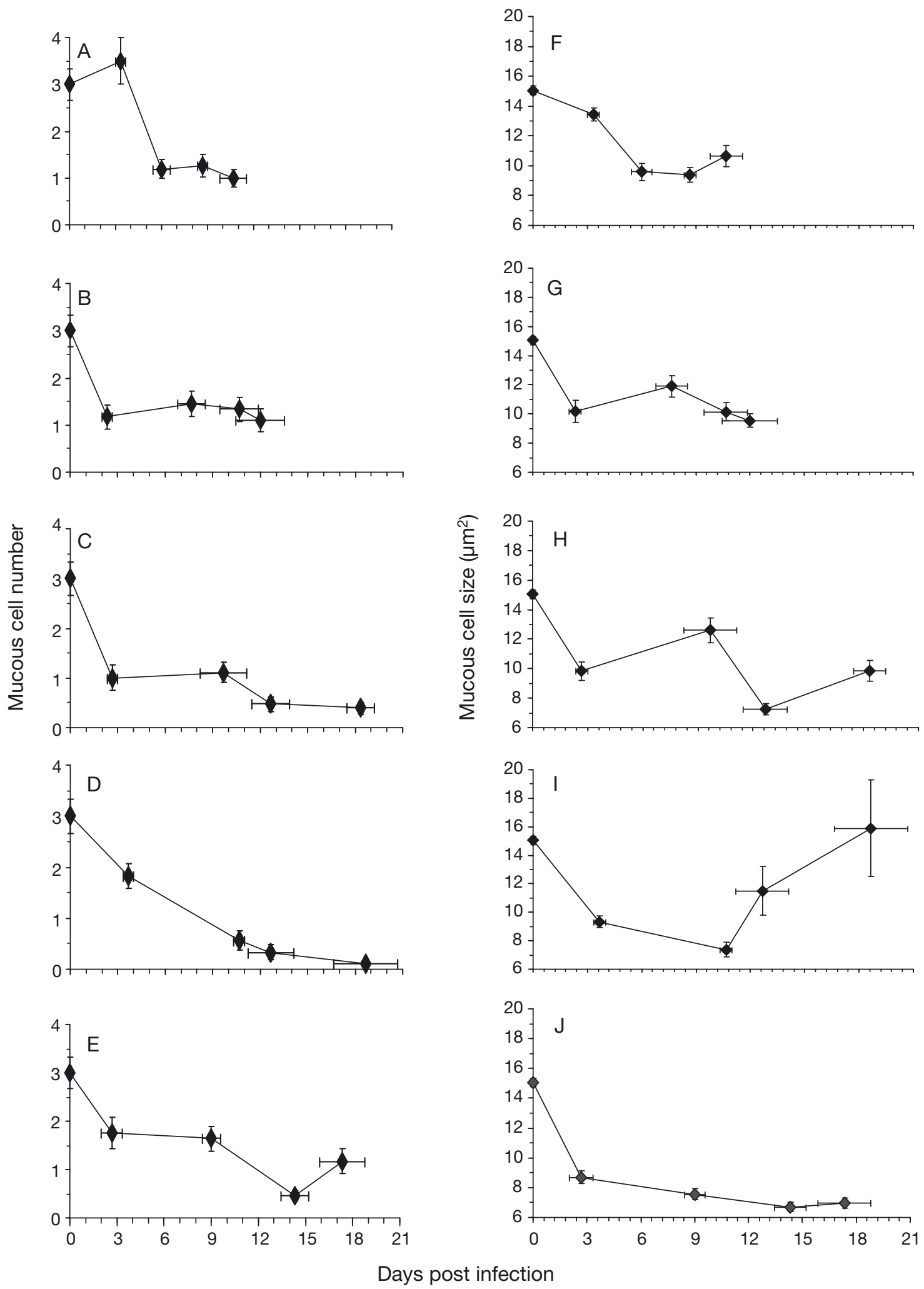

Fig. 4. (A-E) Temporal dynamics of Poecillia reticulata mature mucous cell number and (F-J) mucous cell size $\left(\mu m^{2}\right)$ in re-

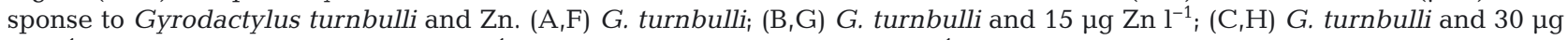

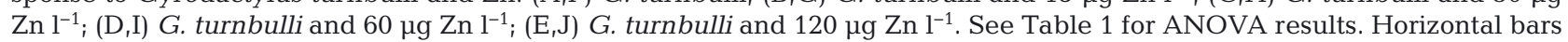
represent SE in the day when fish reach lag, early, middle and late exponential growth phases of infection 
Table 2. Percentage $( \pm \mathrm{SE})$ of mature mucous cells located on the external surface of the epidermis of Poecila reticlata exposed concurrently to Gyrodactylus turnbulli infection and waterborne Zn during 5 phases: pre-exposure; lag period (<6 parasites per fish); early exponential growth phase (approximately 20 parasites per fish); mid-exponential growth phase (approximately 50 parasites per fish); and late exponential growth phase (approximately 100 parasites per fish). Note that the number of days before fish reached each infection phase differed depending on Zn concentration (see Fig. 1)

\begin{tabular}{|c|c|c|c|c|c|}
\hline Infection phase & $0 \mu \mathrm{g} \mathrm{Zn}^{-1}$ & $15 \mu \mathrm{g} \mathrm{Zn} \mathrm{l^{-1 }}$ & $30 \mu \mathrm{g} \mathrm{Zn} \mathrm{^{-1 }}$ & $60 \mu \mathrm{g} \mathrm{Zn} \mathrm{^{-1 }}$ & $120 \mu \mathrm{g} \mathrm{Zn} \mathrm{^{-1 }}$ \\
\hline Pre-exposure & $98 \pm 1$ & $98 \pm 1$ & $98 \pm 1$ & $98 \pm 1$ & $98 \pm 1$ \\
\hline Lag & $97 \pm 2$ & $100 \pm 0$ & $97 \pm 3$ & $95 \pm 3$ & $100 \pm 0$ \\
\hline Early exponential growth & $63 \pm 8$ & $85 \pm 5$ & $97 \pm 3$ & $64 \pm 10$ & $97 \pm 2$ \\
\hline Mid-exponential growth & $73 \pm 7$ & $40 \pm 7$ & $76 \pm 11$ & $100 \pm 0$ & $100 \pm 0$ \\
\hline Late exponential growth & $78 \pm 7$ & $8 \pm 4$ & $86 \pm 10$ & $80 \pm 20$ & $83 \pm 6$ \\
\hline
\end{tabular}

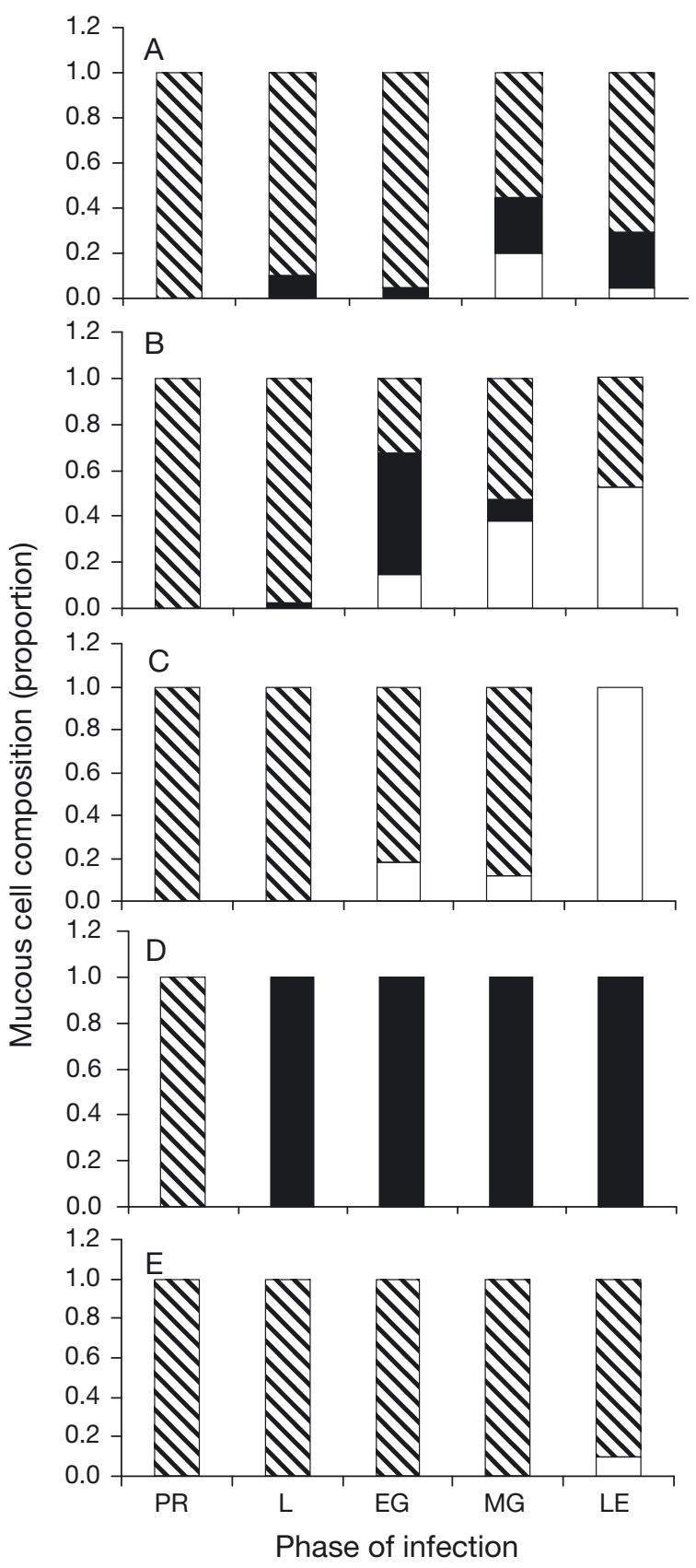

$\mathrm{Zn}^{-1}$ ). In addition, the presence of infection delayed the shift in mucin composition induced by $\mathrm{Zn}$ alone in

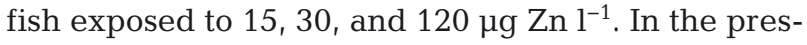
ence of $\mathrm{Zn}$ alone, the shift from mixed neutral and acidic mucins to acidic mucins occurred on Day 3 (Gheorghiu et al. 2009), whereas when fish were also infected, this shift occurred during the early exponential growth (EG) phase (Day 7-8). At $30 \mu \mathrm{gn} \mathrm{l}^{-1}$, the addition of infection delayed the virtually complete shift to neutral mucins from Day 3 in the presence of $\mathrm{Zn}$ alone (Gheorghiu et al. 2009) to the late exponential growth (LE) phase (Day 17). Furthermore, the shift from mixed mucins to acidic mucins in fish exposed only to $120 \mu \mathrm{g} \mathrm{Zn}^{-1}$ (Gheorghiu et al. 2009) never occurred in the presence of gyrodactylid infection. In contrast, and even more intriguing, is

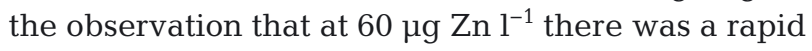
and sustained shift to acidic mucins both in the presence of $\mathrm{Zn}$ alone (Gheorghiu et al. 2009) and in the presence of both stressors. This is quite remarkable. The immediate response of mucus cells to a stress initially is that the surface cells release mucous and that the newly maturing cells differentiate to cells producing either acidic mucins or neutral mucins (McKim \& Lien 2001). Within $3 \mathrm{~d}$ of exposure to as lit-

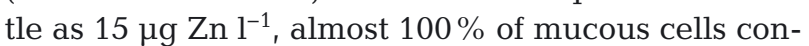
tained one or the other mucin, indicating that the ini-

Fig. 5. Frequency distribution of Poecillia reticulata mucous cell composition in response to Gyrodactylus turnbulli and

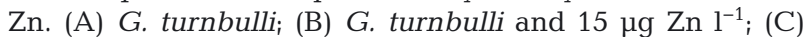

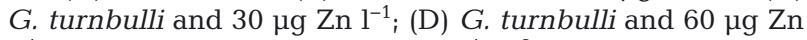
$\mathrm{l}^{-1}$; (E) G. turnbulli and $120 \mu \mathrm{g} \mathrm{Zn} \mathrm{l^{-1 }}$. $\left(\chi^{2} ; \mathrm{p}<0.0001\right)$. Proportion of mucous cells with a mixture of neutral and acidic mucins (striped bars); with acidic mucins (black bars); cells containing neutral mucins (open bars). PR: pre-exposure; L: lag period ( $<6$ parasites per fish); EG: early exponential growth phase (approximately 20 parasites per fish); MG: mid-exponential growth phase (approximately 50 parasites per fish); LG: late exponential growth phase (approximately 100 parasites per fish) 
tial population of mucous cells has been sloughed off and that new cells have reached the surface of the epidermis. Yet, when a few gyrodactylids were added, the mucous cells continued to contain a mixture of neutral and acidic mucins, indicating either that the cells have not been sloughed off, or that a differentiation process has not been initiated. Release of acidic mucins is believed to be a protective mechanism against infection (Lester 1972) as well as waterborne Zn (Handy et al. 1989, Shephard 1994), suggesting that gyrodactylids may release a suppressive factor that promotes their initial establishment and survival. Although other helminth parasites induce immunosuppression in their fish hosts (Secombes \& Chappell 1996), these initial skin responses to gyrodactylids and to the combined effect of gyrodactylids and $\mathrm{Zn}$ have not been previously documented, and the possibility that gyrodactylids exert a suppressive effect on mucus release or mucin formation warrants further investigation.

After a few days, Gyrodactylus turnbulli numbers increased rapidly, reaching 100 parasites within

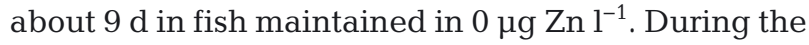
exponential growth phase, infection alone induced a significant reduction in mucous cell numbers. Both thickening of the epidermis and low numbers of mucous cells were maintained at the same level for the whole exponential growth phase, with no evidence of the recurring fluctuations that we observed in response to Zn alone (Gheorghiu et al. 2009). Similar epidermal responses have been reported in response to a variety of species of Gyrodactylus, regardless of the host, the type of study (field or experimental), or the intensity of infection at the moment of sampling (Wells \& Cone 1990, Appleby et al. 1997, Sterud et al. 1998). As epithelial browsers, gyrodactylids destroy both epithelial and mucous cells in the epidermis (Wells \& Cone 1990, Sterud et al. 1998). In response, multipotent progenitor cells are more likely to differentiate into epithelial cells at the expense of mucous cells, simply because epithelial cells are the predominant cell type. Hyperplasia of epithelial cells will, in turn, cause thickening of the epidermis despite the loss of epidermal cells that are sloughed off in response to parasites (Wells \& Cone 1990). Unlike exposure to $\mathrm{Zn}$ alone (Gheorghiu et al. 2009), infection alone had only a modest impact on mucin composition. Consistent with evidence that more acidic mucins are produced in response to gyrodactylids on sticklebacks (Lester 1972), we found that approximately $20 \%$ of mucous cells contained only acidic mucins during mid- and late exponential growth phases of infection.
When both stresses were combined, the late exponential phase was delayed until approximately Day 17 in fish exposed to 30,60 , or $120 \mathrm{\mu g} \mathrm{l}^{-1} \mathrm{Zn}$. This is consistent with our previous data, showing that the time to reach peak parasite numbers was delayed in a Zn concentration-dependent manner (Gheorghiu et al. 2006) and that both parasite lifespan and number of offspring per parasite were reduced at these Zn concentrations (Gheorghiu et al. 2007).

We had hypothesized that the slower exponential growth of Gyrodactylus turnbulli populations on guppies also exposed to waterborne $\mathrm{Zn}$ compared to those exposed to infection alone (Gheorghiu et al. 2007) may have been linked to altered epidermal responses. Between Days 6 and 18, combined exposure to $\mathrm{Zn}$ and gyrodactylid infection induced fluctuating epidermal thickness at concentrations $>15 \mu \mathrm{Zn} \mathrm{l}^{-1}$, a response characteristic of exposure to $\mathrm{Zn}$ alone (Gheorghiu et al. 2009). Epidermal thickening and associated hyperplasia has been reported as a general adaptive response to a variety of stressors (Whitear 1986, Wells \& Cone 1990, Iger et al. 1994, Sterud et al. 1998), and thickening and increase in number of cell layers were observed in response to both infection and to Zn. However, whereas infection alone induced a stable increase of about $50 \%$ in epidermal thickness, Zn alone (Gheorghiu et al. 2009) and Zn combined with infection both induced dramatic fluctuations in epidermal thickness, especially at higher zinc concentrations. Furthermore, the thickness of the epidermis never dropped below control values in fish exposed to the combination of stressors, which it did in fish exposed to Zn alone (Gheorghiu et al. 2009).

Whereas we account for the fluctuating pattern of epidermal thickness as a response to $\mathrm{Zn}$, we suggest that the sustained decrease in number of mucous cells in fish exposed to both stresses was a response to infection. Although mucous cell numbers declined initially in response to $\mathrm{Zn}$ alone, mucous cell numbers fluctuated over time (Gheorghiu et al. 2009). This indicates that the presence of increasing numbers of parasites leads to long-term reduction in mucous cell numbers, a feature that may promote persistence of the parasite. It would be of interest to determine whether this same pattern is seen on fish that are able to recover from infection.

Finally, we had hypothesized that the evidence of acclimation of the epidermal tissue observed in response to $\mathrm{Zn}$ alone (Gheorghiu et al. 2009) would also be observed in response to the combined stresses of $\mathrm{Zn}$ and infection. In fish exposed to $\mathrm{Zn}$ alone for up to $30 \mathrm{~d}$, fluctuations in epidermal variables had dampened by Day 18, suggesting that the 
fish may have become acclimated to the waterborne Zn (Gheorghiu et al. 2009). The present study provides little evidence of acclimation of the epidermis. This may be because of the continually escalating stress to the fish as parasite numbers increased. Alternatively, the duration of observations may have been too short to detect acclimation.

Taken together, our present results showed that the fish epidermis responded to both $\mathrm{Zn}$ exposure and gyrodactylid infection, and that the responses differed with concentration of Zn, duration of exposure, and intensity of infection. Initial responses were most likely protective against both Zn toxicity (through increased mucus production, with more acidic composition) and infection (increased epidermal thickness and mucous cell number). As concentration of $\mathrm{Zn}$ and parasite numbers increased, the epidermal responses indicated disturbed host response (dramatic decline in mucous cell numbers, with mixed composition of mucins), which would have been less effective against Zn toxicity and infection. Combined damage induced by both stressors could account for the concentration-dependent elevation in mortality previously recorded in infected guppies concurrently exposed to Zn (Gheorghiu et al. 2006). Thus, as parasite numbers increased, the parasite-induced damage to the epidermis most likely facilitated entry of Zn into inner tissues.

In conclusion, these results indicate that when exposed to both Zn and Gyrodactylus turnbulli infection, fish have an impaired epidermal response, which on the one hand will not be able to limit or clear the infection, and on the other hand will no longer prevent the absorption of $\mathrm{Zn}$ into the body. Moreover, when combining 2 stressors, due to unexpected and context-dependent interactive effects, results are not necessarily linear (Marcogliese \& Pietrock 2011). This is particularly important in interpreting physiological and toxicological responses in the field, when organisms are subjected to not only pollutants but pathogens as well.

Acknowledgements. Funding for this research was provided by the Natural Sciences and Engineering Research Council, Canada (NSERC 3585), together with the St. Lawrence Action Plan (Environment Canada). C.G. also acknowledges an NSERC postgraduate scholarship. Research at the Institute of Parasitology is supported by a Regroupement Stratégique from Le Fonds de recherche du Québec Nature et technologies (FQRNT) (a provincial funding agency). We extend special thanks to Dr. Michel Assad and his team of technicians from The Centre for Bone and Periodontal Research (McGill University), who kindly helped us with the histological processing of our samples, and to the anonymous reviewers for their helpful suggestions.

\section{LITERATURE CITED}

Appleby C, Mo TA, Aase IL (1997) The effect of Gyrodactylus salaris (Monogenea) on the epidermis of Atlantic salmon, Salmo salar, parr in the river Batnfjordselva, Norway. J Parasitol 83:1173-1174

> Barker DE, Cone DK, Burt MDB (2002) Trichodina murmanica (Ciliophora) and Gyrodactylus pleuronecti parasitizing hatchery-reared winter flounder, Pseudopleuronectes americanus (Walbaum): effects on host growth and assessment of parasite interaction. J Fish Dis 25: 81-89

Bowen L, Werner I, Johnson ML (2006) Physiological and behavioural effects of zinc and temperature on coho salmon (Oncorhynchus kisutch). Hydrobiologia 559: 161-168

Buchmann K (1999) Immune mechanisms in fish skin against monogeneans - a model. Folia Parasitol 46:1-9

Buchmann K, Bresciani J (1998) Microenvironment of Gyrodactylus derjavini on rainbow trout Oncorhynchus mykiss: association between mucous cell density in skin and site selection. Parasitol Res 84:17-24

- Buchmann K, Lindenstrøm T (2002) Interactions between monogenean parasites and their fish hosts. Int J Parasitol 32:309-319

Canadian Council of Ministers of the Environment (2005) Canadian water quality guidelines (CWQG) for the protection of aquatic life. www.ccme.ca/assets/pdf/wqg_ aql_summary_table.pdf

Canadian Council on Animal Care (2005) Guidelines on the care and use of fish in research, teaching and testing. www.ccac.ca/en/CCAC_Programs/Guidelines_Policies/ GDLINES/Fish/FishGuidelinesEnglish.pdf

Cone DK (1999) Monogenea. In: Woo PTK (ed) Fish diseases and disorders, Vol 1. Protozoan and metazoan infections. CABI Publishing, Wallingford, p 289-327

> Cousins RJ (1998) A role of zinc in the regulation of gene expression. Proc Nutr Soc 57:307-311

Cross MA, Irwin SWB, Fitzpatrick SM (2001) Effects of heavy metal pollution on swimming and longevity in cercariae of Cryptocotyle lingua (Digenea: Heterophidae). Parasitology 123:499-507

- Gheorghiu C, Cable J, Marcogliese DJ, Scott ME (2007) Effects of waterborne zinc on reproduction, survival and morphometrics of Gyrodactylus turnbulli (Monogenea) on guppies (Poecilia reticulata). Int $\mathrm{J}$ Parasitol 37: 375-381

> Gheorghiu C, Marcogliese DJ, Scott ME (2009) Temporal dynamics of epidermal responses of guppies Poecilia reticulata to a sublethal range of waterborne zinc concentrations. J Fish Biol 75:2642-2656

> Gheorgiu C [sic], Marcogliese DJ, Scott M (2006) Concentration-dependent effects of waterborne zinc on population dynamics of Gyrodactylus turnbulli (Monogenea) on isolated guppies (Poecilia reticulata). Parasitology 132: 225-232

> Handy RD, Eddy FB, Romain G (1989) In vitro evidence for the ionoregulatory role of rainbow trout mucus in acid, acid/aluminium and zinc toxicity. J Fish Biol 35:737-747

> Harris PD, Cable J, Tinsley RC, Lazarus CM (1999) Combined ribosomal DNA and morphological analysis of individual gyrodactylid monogeneans. J Parasitol 85: 188-191

- Hirmo S, Kelm S, Iwersen M, Hotta K and others (1998) Inhibition of Helicobacter pylori sialic acid-specific haemag- 
glutination by human gastrointestinal mucins and milk glycoproteins. FEMS Immunol Med Microbiol 20: 275-281

Iger Y, Jenner H, Wendelaar Bonga SE (1994) Cellular responses in the skin of rainbow trout (Oncorhynchus mykiss) exposed to Rhine water. J Fish Biol 45: 1119-1132

Kamisago S, Iwamori M, Tai T, Mitamura K, Yazaki Y, Sugano K (1996) Role of sulfatides in adhesion of Helicobacter pylori to gastric cancer cells. Infect Immun 64: 624-628

Kearn GC (1998) Parasitism and the platyhelminths. Chapman \& Hall, London

Lester RJG (1972) Attachment of Gyrodactylus to Gasterosteus and host response. J Parasitol 58:717-722

Lester RJG, Adams JR (1974) Gyrodactylus alexandri: reproduction, mortality, and effect on its host Gasterosteus aculeatus. Can J Zool 52:827-833

Marcogliese DJ, Pietrock M (2011) Combined effects of parasites and contaminants on animal health: parasites do matter. Trends Parasitol 27:123-130

McKim JM, Lien GJ (2001) Toxic responses of the skin. In: Schlenk D, Benson WH (ed) Target organ toxicity in marine and freshwater teleosts: organs. Taylor \& Francis, New York, NY, p 203-204

Morley NJ, Crane M, Lewis JW (2003a) Toxicity of cadmium and zinc to the cercarial activity of Diplostomum spathaceum (Tremadoda:Diplostomidae). Folia Parasitol 50: $57-60$

> Morley NJ, Crane M, Lewis JW (2003b) Effects of cadmium and zinc toxicity on orientation behaviour of Echinoparyphium recurvatum (Digenea: Echinostomidae) cercariae. Dis Aquat Org 56:89-92

Pietrock M, Goater CP (2005) Infectivity of Ornithodiplostomum ptychocheilus and Posthodiplostomum minimum (Trematoda: Diplostomidae) cercariae following exposure to cadmium. J Parasitol 91:854-856

Richards GR, Chubb JC (1996) Host response to initial and challenge infections, following treatment, of Gyrodactylus bullatarudis and Gyrodactylus turnbulli (Monogenea) on the guppy (Poecilia reticulata). Parasitol Res 82:242-247

Richards GR, Chubb JC (1998) Long-term population dynamics of Gyrodactylus bullatarudis and G. turnbulli (Monogenea) on adult guppies (Poecilia reticulata) in 50-1 experimental arenas. Parasitol Res 84:753-756

Scott ME (1982) Reproductive potential of Gyrodactylus bullatarudis (Monogenea) on guppies (Poecilia reticulata). Parasitology 85:217-236

Scott ME (1985) Dynamics of challenge infections of Gyrodactylus bullatarudis Turnbull (Monogenea) on guppies, Poecilia reticulata (Peters). J Fish Dis 8:495-503

Scott ME, Anderson RM (1984) The population dynamics of

Editorial responsibility: Bernd Sures,

Essen, Germany
Gyrodactylus bullatarudis (Monogenea) within laboratory populations of the fish host Poecilia reticulata. Parasitology 89:59-94

Scott ME, Robinson MA (1984) Challenge infections of Gyrodactylus bullatarudis (Monogenea) on guppies, Poecilia reticulata (Peters), following treatment. J Fish Biol 24:581-586

Secombes CJ, Chappell LH (1996) Fish immune responses to experimental and natural infection with helminth parasites. Annu Rev Fish Dis 6:167-177

Shephard KL (1994) Functions for fish mucus. Rev Fish Biol Fish 4:401-429

Sinha GM, Chakravorty P (1982) Characterization and distribution of neutral and acidic mucins in the alimentary canal of an Indian freshwater major carp, Catla catla (Hamilton) by histochemical methods. Gegenbaurs Morphol Jahrb 128:188-200

> Sterud E, Harris PD, Bakke TA (1998) The influence of Gyrodactylus salaris Malmberg 1957 (Monogenea) on the epidermis of Atlantic salmon, Salmo salar L., and brook trout, Salvelinus fontinalis (Mitchill): experimental studies. J Fish Dis 21:257-263

Sures B (2002) Competition for minerals between Acanthocephalus lucii and its definitive host perch (Perca fluviatilis). Int J Parasitol 32:1117-1122

Thielen F, Zimmermann S, Baska F, Taraschewski H, Sures B (2004) The intestinal parasite Pomphorhynchus laevis (Acanthocephala) from barbel as a bioindicator for metal pollution in the Danube River near Budapest, Hungary. Environ Pollut 129:421-429

Tibbetts IR (1997) The distribution of mucous cells and their secretions in the alimentary tract of Arrhamphus sclerolepis. J Fish Biol 50:809-820

Vallee BL, Falchuk KH (1993) The biochemical basis of zinc physiology. Physiol Rev 73:79-118

Watanabe T, Kiron V, Satoh S (1997) Trace minerals in fish nutrition. Aquaculture 151:185-207

Wells PR, Cone DK (1990) Experimental studies on the effect of Gyrodactylus colemanensis and G. salmonis (Monogenea) on density of mucous cells in the epidermis of fry of Oncorhynchus mykiss. J Fish Biol 37:599-603

Whitear M (1986) Epidermis. In: Bereiter-Hahn J, Matoltsy AG, Richards KS (eds) Biology of the integument. II. Vertebrates. Springer Verlag, Berlin, p 8-38

- Widianarko B, van Gestel CAM, Verweij RA, van Straalen NM (2000) Associations between trace metals in sediment, water, and guppy, Poecilia reticulata (Peters), from urban streams of Semarag, Indonesia. Ecotoxicol Environ Saf 46:101-107

> Widianarko B, Kuntoro FXS, van Gestel CAM, Verweij RA, van Straalen NM (2001) Toxicokinetics and toxicity of zinc under time-varying exposure in the guppy (Poecilia reticulata). Environ Toxicol Chem 20:763-768

Submitted: September 26, 2011; Accepted: December 19, 2011 Proofs received from author(s): March 5, 2012 